\title{
Morphological coupling in multiple sandbar systems - a review
}

\author{
T. D. Price ${ }^{1, *}$, B. G. Ruessink ${ }^{1}$, and B. Castelle ${ }^{2}$ \\ ${ }^{1}$ Department of Physical Geography, Faculty of Geosciences, Utrecht University, Utrecht, the Netherlands \\ ${ }^{2}$ UMR EPOC, Université de Bordeaux 1, Bordeaux, France \\ *now at: Department of Ecological Science, Faculty of Earth and Life Sciences, VU University Amsterdam, \\ Amsterdam, the Netherlands \\ Correspondence to: T. D. Price (t.d.price@vu.nl)
}

Received: 15 October 2013 - Published in Earth Surf. Dynam. Discuss.: 10 December 2013

Revised: 22 April 2014 - Accepted: 25 April 2014 - Published: 3 June 2014

\begin{abstract}
Subtidal sandbars often exhibit alongshore variable patterns, such as crescentic plan shapes and rip channels. While the initial formation of these patterns is reasonably well understood, the morphodynamic mechanisms underlying their subsequent finite-amplitude behaviour have been examined far less extensively. This behaviour concerns, among other aspects, the coupling of alongshore variable patterns in an inner bar to similar patterns in a more seaward bar, and the destruction of crescentic patterns. This review aims to present the current state of knowledge on the finite-amplitude behaviour of crescentic sandbars, with a focus on morphological coupling in double sandbar systems. In this context we include results from our recent study, based on a combination of remote-sensing observations, numerical modelling and data-model integration. Morphological coupling is an inherent property of double sandbar systems, where the inner bar may attain a type of morphology not found in single bar systems. Coupling is governed by water depth variability along the outer-bar crest and by various wave characteristics, including the offshore wave height and angle of incidence. In recent research, the role of the angle of wave incidence for sandbar morphodynamics has received more attention. Numerical modelling results have demonstrated that the angle of wave incidence is crucial to the flow pattern, sediment transport, and thus the emerging morphology of the coupled inner bar. Moreover, crescentic patterns predominantly vanish under highangle wave conditions, highlighting the role of alongshore currents in straightening sandbars and challenging the traditional conception that crescentic patterns vanish under high-energy, erosive wave conditions only.
\end{abstract}

\section{Introduction}

Subtidal sandbars are shore-parallel ridges of sand in less than $10 \mathrm{~m}$ water depth fringing wave-dominated coasts along great lakes, semi-enclosed seas and open oceans (e.g. Evans, 1940; Saylor and Hands, 1970; Greenwood and DavidsonArnott, 1975; Lippmann et al., 1993; Ruessink and Kroon, 1994; Shand et al., 1999; Almar et al., 2010; Kuriyama, 2002; Ruessink et al., 2003; Wijnberg and Terwindt, 1995, and references therein). Sandbars often have multi-annual lifetimes and can occur as a single feature, or as a multiple bar (most often two, sometimes up to five) system. Intriguingly, sandbars often exhibit quasi-regular undulations in their height and cross-shore position (Fig. 1). These so- called crescentic sandbars can be viewed as a more-or-less rhythmic sequence of shallow horns (shoals) and deep bays (cross-shore troughs) alternating shoreward and seaward of an imaginary line parallel to the coast. In addition, crescentic sandbars are often associated with similar rhythmic perturbations in onshore morphology, such as the shoreline (e.g. Sonu, 1973; Van de Lageweg et al., 2013) or a more landward located inner sandbar (e.g. Ruessink et al., 2007a). Depending on the wave conditions and the currents they induce in the nearshore zone, these sandbar patterns continuously change, vanish or reappear. It is this perpetual variability of nearshore sandbars that continues to draw the attention of nearshore researchers, just as it has done over the past decades. 


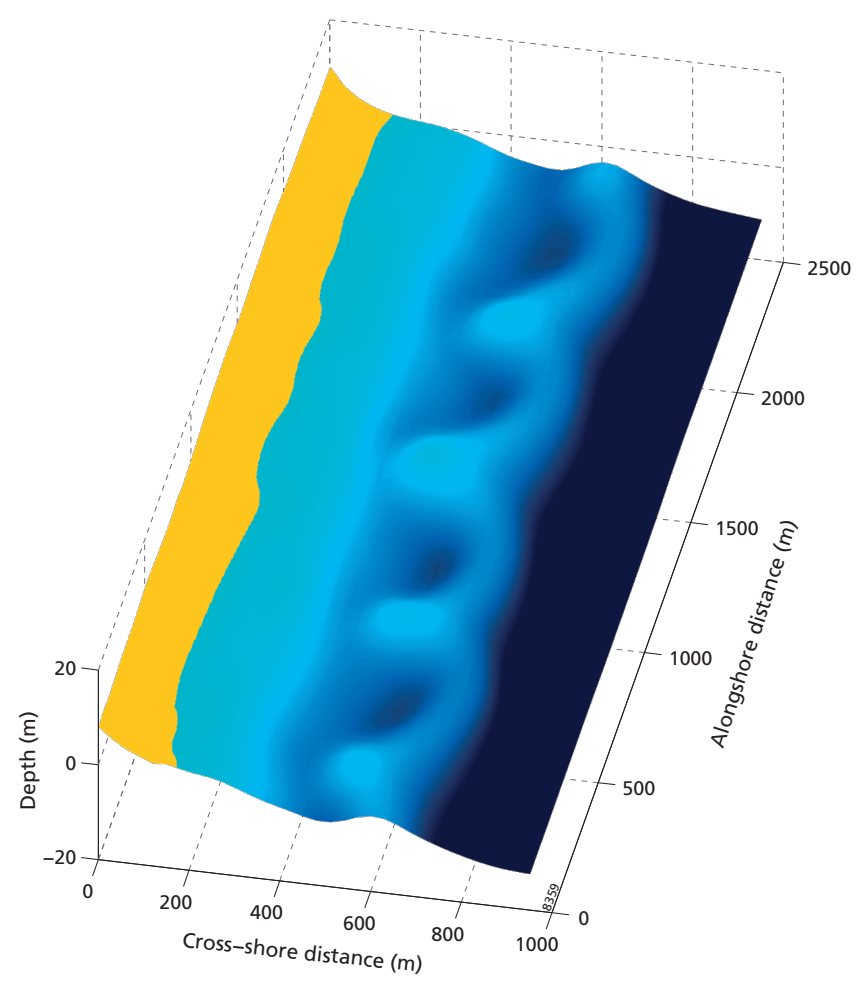

Figure 1. Bathymetry of a beach with a crescentic sandbar. This bathymetry was measured during the ECORS-Truc Vert 2008 field experiment (see Almar et al. 2010).

Besides their intriguing morphological appearance and evolution, sandbars are also of significant societal importance by forming a natural barrier between the hinterland and the ocean. Sandbars safeguard beaches by dissipating storm waves before they impact the shore. Morphological coupling, for instance, can lead to alongshore variations in wave dissipation, resulting in localised beach and dune erosion and subsequent property loss during storms (Thornton et al., 2007). Many present-day soft engineering measures to improve coastal safety, such as shoreface nourishments, involve direct or indirect modifications to sandbars (e.g. Grunnet and Ruessink, 2005; Ojeda and Guillén, 2008). A comprehensive understanding of the processes that govern sandbar behaviour and the development of the capability to predict this behaviour are thus of significant importance when it comes to minimising human and economic losses.

A key element to the understanding of morphological sandbar behaviour is frequent (daily), and long-term ( $\sim$ years) monitoring of the nearshore zone, and the subsequent investigation of patterns and regularities in behaviour emerging from this observational data. Numerous observations and long-term monitoring of the nearshore zone have revealed the wide range of shapes that nearshore sandbars may attain (e.g. Wright and Short, 1984; Lippmann and Holman, 1990; Van Enckevort et al., 2004; Ranasinghe et al., 2004). Despite each observed sandbar configuration being unique, and the continuous change in shape under the influence of waves and currents, a certain regularity in sandbar morphology has been observed. For single-barred beaches, Wright and Short (1984) developed the most widely accepted and applied beach state classification model, based on observations of beaches with contrasting environmental conditions over a period of 3 years. Such an aggregation facilitates answers as to when certain behaviour, such as morphological coupling, actually happens. Whereas the Wright and Short (1984) classification model is essentially applicable to single-barred beaches only, Short and Aagaard (1993) devised a multi-bar state model where each bar can go through the same states as in the single bar model. The sandbars are essentially treated as independent features and the role of coupling between the bars for the behaviour of the composite double sandbar system is thus disregarded.

Another key approach to the understanding of sandbar dynamics is the development, use, and validation of simplified exploratory and detailed simulation models. Model studies first explained alongshore sandbar variability from a $h y$ drodynamic template in the water motion (Bowen and Inman, 1971; Holman and Bowen, 1982); present-day models rely on the principle of self-organisation (Hino, 1975; Sonu, 1972; Falqués et al., 2000; Coco and Murray, 2007), in which a crescentic sandbar forms spontaneously through the positive feedback between the flow, sediment processes and the evolving morphology. The genesis of crescentic patterns in single sandbar systems is thus reasonably well understood. In a double sandbar system, with a more landward inner bar and a more seaward outer bar, the distinction between a forcing template and self-organisation becomes blurred (Castelle et al., 2010a, b). In this case, the crescentic outer-bar morphology acts as a morphological template for the inshore flow patterns through the breaking and focussing of waves across the outer bar. It is obvious that this morphological coupling no longer relates to the initial formation of patterns, but relates to finite-amplitude behaviour instead. Here, the morphological template of the crescentic outer bar may suppress local self-organisation mechanisms at the inner bar and hence govern the shape of the inner bar.

Although morphological coupling has been observed and finite-amplitude behaviour of sandbars has been shown to be one of the largest sources of nearshore morphodynamic variability, it is not understood when and why morphological variations in an outer bar impact the geometry of an inner bar. The increasing availability of high-resolution (daily), longterm (many years) time series of nearshore video imagery (Holman and Stanley, 2007), together with advances in the non-linear modelling of nearshore morphodynamics and in data-model integration techniques, have recently advanced our knowledge of the finite-amplitude behaviour of alongshore sandbar variability considerably.

This review aims to present the current state of knowledge on the finite-amplitude behaviour of crescentic sandbars, with a focus on morphological coupling in double sandbar 


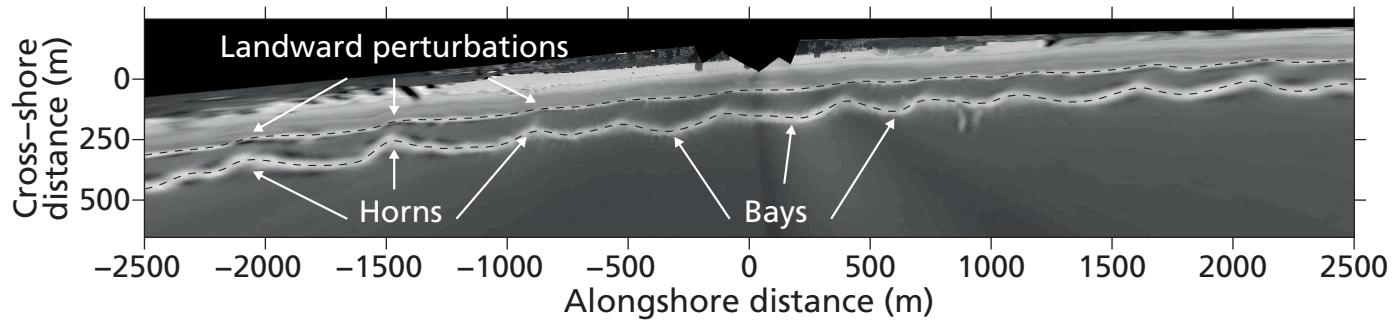

Figure 2. Example of a time-exposure image from the Gold Coast, Australia, showing the Idt coupling type, with a crescentic outer bar and a terraced inner bar with landward perturbations coupled to the alongshore positions of the outer-bar horns. The dotted lines indicate the video-derived inner and outer barlines. Source: Price et al. (2013).

systems. In this context we include results from our recent study, based on an approximately 9.3-year long data set of low-tide time-exposure video images of the double-barred Surfers Paradise, Gold Coast, Queensland, Australia, a swelldominated site where the waves are usually obliquely incident. Measurements from nearby wave buoys provided concurrent wave data, i.e. root-mean-square wave height $H_{\text {rms }}$, peak wave period $T_{\mathrm{p}}$ and angle of wave incidence with respect to shore-normal in $15 \mathrm{~m}$ depth $\theta$. First, the morphodynamic states that characterise a double sandbar system are described in Sect. 2, followed by a discussion of observations and modelling efforts of morphological coupling in double sandbar systems in Sect. 3. In Sect. 4, we conclude with a brief synthesis and perspectives for future research.

\section{Alongshore sandbar variability}

Although considerable research has been devoted to the state dynamics of a double-barred system, observations were mostly based on data which were either temporally limited to a single accretionary/erosional sequence (e.g. Van Enckevort et al., 2004; Ruessink et al., 2007a), spatially limited to (an alongshore transect of) the inner bar (e.g. Lippmann and Holman, 1990; Shand et al., 2003; Sénéchal et al., 2009) or based on data acquired at different locations or at irregular intervals (Short and Aagaard, 1993; Castelle et al., 2007). Furthermore, the large relaxation times of outer bars, in relation to the offshore wave forcing, have often prevented an abundance of state transitions of the outer bar to occur during the studied periods (see e.g. Goldsmith et al., 1982; Ferrer et al., 2009). While these observations each provide a varying amount of insight into sandbar behaviour, the use of scarce data or the selective use of data carries the risk of assuming the identified behaviour to be representative of the characteristic system dynamics. With the rise of video monitoring of the nearshore zone over the last 3 decades (Holman and Stanley, 2007), the trend towards frequent, long-term monitoring is increasing. The sequential behaviour of the bar states of a double-barred system at a single site, however, had not been studied under a wide range of wave conditions. Accordingly, an important first step in our study of the finite-amplitude behaviour of crescentic sandbars was to characterise the typical development of alongshore variability within a double sandbar system, based on multiple sequences (see Price and Ruessink, 2011).

The most conspicuous elements in the low-tide timeexposure images mentioned in Sect. 1 are the alongshore continuous white bands that represent the foam created by wave breaking above the sandbars (Lippmann and Holman, 1989; Fig. 2). We tracked this optical breaker line (hereafter referred to as the barline) of both the inner and outer bar in all available (2995) low-tide images, allowing us to quantify the alongshore variability of both bars (see Price and Ruessink, 2011). During the 9.3 years studied, the outer bar was predominantly (two thirds of the time) alongshore variable, whereas the inner bar existed as a shore-attached terrace with a rhythmic terrace edge almost half of the time (shown in Fig. 2). This alongshore rhythmicity of the inner terrace contrasts with shore-attached terraces in single bar systems, which are mostly alongshore-uniform. For more alongshoreuniform outer-bar shapes (a third of the time), an inner terrace was less common and, instead, rip channels dominated the inner-bar morphology.

As mentioned in Sect. 1, the development of crescentic sandbars has been attributed to self-organisation processes, with the traditional conception that the wave energy alone governs their evolution. The development of crescentic sandbars has been found to develop during low-energy, accretive wave conditions (e.g. Ranasinghe et al., 2004; Van Enckevort et al., 2004); a so-called downstate sequence (Wright and Short, 1984). Their alongshore variability is associated with wave-driven circulation patterns that consist of weak onshore flow over the horns and strong offshore flow through the bays. Under continuing low waves the horns of the crescentic bar weld to the shore, causing the initially alongshore continuous trough to disappear and the bays to evolve into distinct cross-shore troughs (rip channels) with strong currents (up to $2 \mathrm{~m} \mathrm{~s}^{-1}$ ) (e.g. Brander, 1999; Houser et al., 2013). On the other hand, the straightening of an alongshore variable sandbar, called an upstate sequence (Wright and Short, 1984) or morphological reset, has traditionally been associated with 

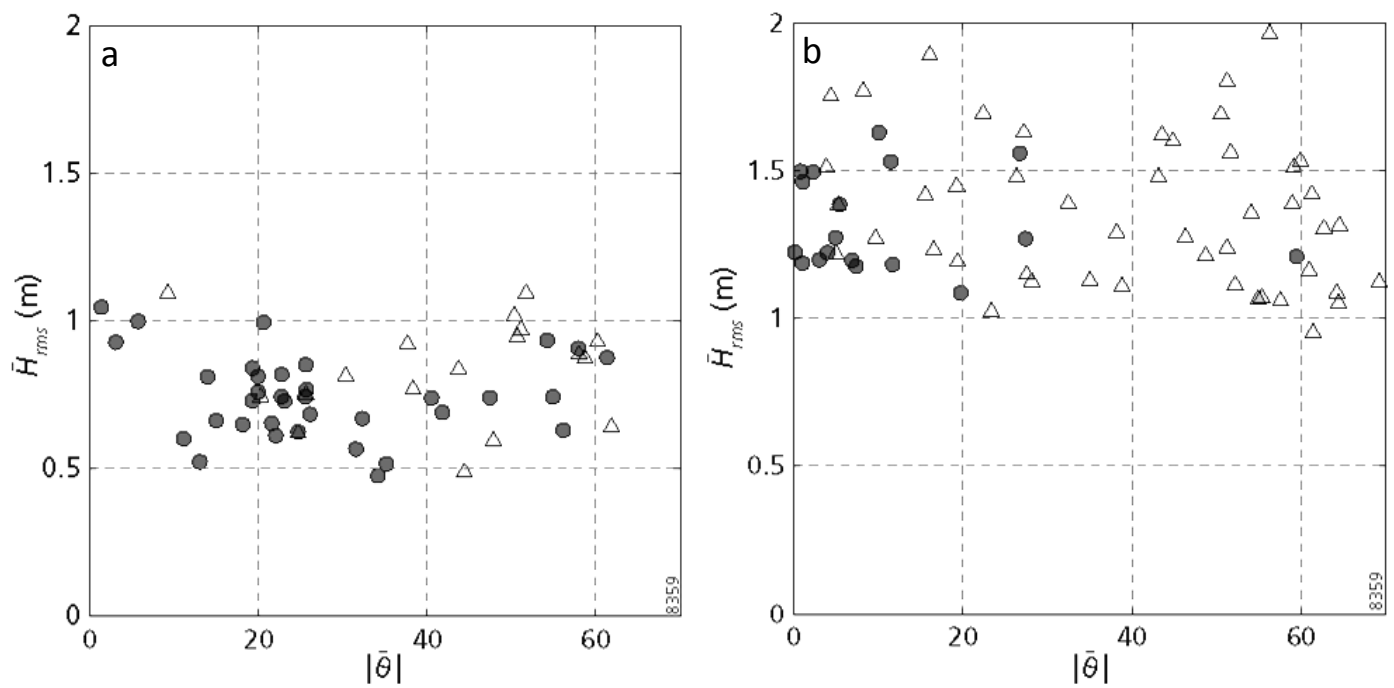

Figure 3. Mean wave conditions during (a) low-energetic and (b) moderately energetic downstate (circles) and upstate (triangles) transitions of the outer bar, showing $\bar{H}_{\text {rms }}$ versus $|\bar{\theta}|$. A downstate transition corresponds to the further development of rip channels, an upstate transition to a sandbar straightening. Adapted from: Price and Ruessink (2011).

high-energy, erosive-wave conditions, without an actual account of which processes lead to straightening.

Observations from the Gold Coast video data set challenge the need for high-energy wave conditions for the straightening of an alongshore variable sandbar; instead, they stress the effect of wave obliquity in morphological evolution. For example, Fig. 3a illustrates that low-energetic wave conditions $\left(\bar{H}_{\mathrm{rms}}=0.5-1 \mathrm{~m}\right)$ generally resulted in the further development of rip channels in the outer bar, especially when $\theta$ is small (say, less than $30^{\circ}$ ), while the same waves with a larger angle of incidence $\left(\theta>20^{\circ}\right)$ were observed to cause a reset. Similarly, Fig. $3 \mathrm{~b}$ illustrates that moderately energetic wave conditions $\left(\bar{H}_{\mathrm{rms}}=1-2 \mathrm{~m}\right)$ generally led to sandbar straightening, while the further development of rip channels was observed during smaller angles of wave incidence $\left(\theta<30^{\circ}\right)$. The straightening of a shore-attached crescentic sandbar to a shore-parallel linear bar by obliquely incident waves generally happened gradually (1-5 days). During this transition, the barline straightened and the rip channels became obliquely oriented, leading to a characteristic sandbar morphology (Fig. 4).

Whereas the morphodynamics of the outer bar at the Gold Coast could be related to offshore wave conditions (as a single bar system), two types of inner-bar morphodynamics were distinguished, governed by the outer-bar state: the inner bar mostly existed as an alongshore variable terrace for alongshore variable outer-bar states. As more wave energy reached the inner bar during alongshore-uniform outerbar states, the inner-bar behaviour resembled more that of a single-barred system, with its frequent separation from the shoreline and the persistent development of rip channels. This interaction implies that sandbars in a double-barred system should not be studied as independent features, but that

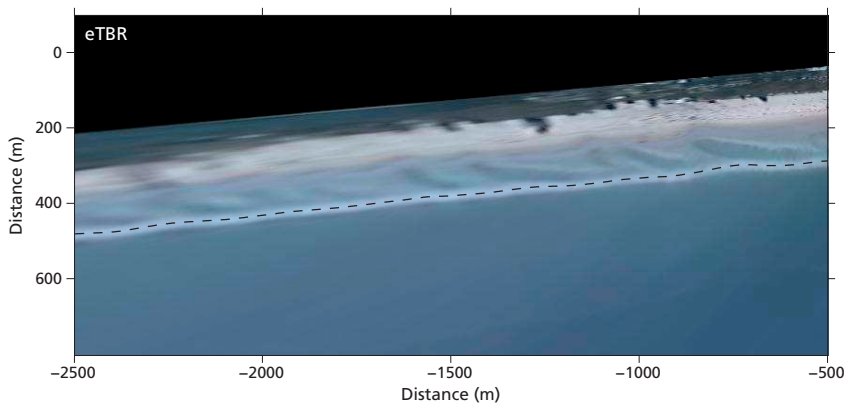

Figure 4. Example of the characteristic sandbar morphology during the straightening of a shore-attached crescentic sandbar to a shoreparallel linear bar by obliquely incident waves. Here, the barline (dashed line) straightens and the rip channels become obliquely oriented. Adapted from: Price and Ruessink (2011).

the behaviour of the composite sandbar system should be taken into account.

\section{Sandbar coupling}

\subsection{Observations}

Various observations indicate that the inner bar may possess remarkably smaller and often more variable alongshore scales than the outer bar (e.g. Bowman and Goldsmith, 1983; Van Enckevort et al., 2004). This has long been interpreted as self-organisation at the scale of the individual bar and the absence of interaction between sandbars. Other observations, summarised in Castelle et al. (2010a), demonstrate that innerbar patterns can also couple to those in the outer bar, indicative of a type of interaction that Castelle et al. (2010a) termed 

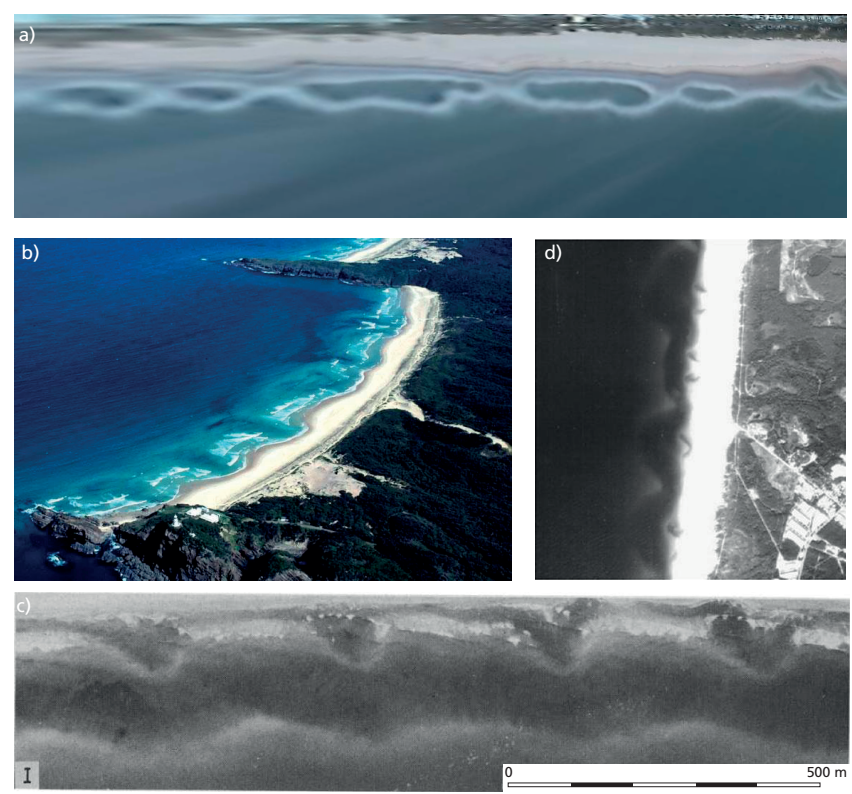

Figure 5. Examples of coupled morphology, showing (a) out-ofphase $\left(180^{\circ}\right)$ coupled sandbars, (b) out-of-phase coupling between sandbar and shoreline (courtesy of A.D. Short), (c) in-phase $\left(0^{\circ}\right)$ coupled sandbars (taken from Bowman and Goldsmith, 1983), and (d) two inner-bar rip channels for each outer-bar bay (taken from Castelle et al., 2007).

morphological coupling. Ruessink et al. (2007a), for example, found that the inner bar increasingly coupled to the outerbar shape as the outer bar became more crescentic and migrated onshore, i.e. during a downstate transition of the outer bar (Wright and Short, 1984; Price and Ruessink, 2011). Coupling examples (Fig. 5) include the systematic occurrence of two inner-bar rip channels within one outer-bar crescent (Castelle et al., 2007; Fig. 5d), that of seaward perturbations in the inner bar facing outer-bar horns (a $180^{\circ}$, or outof-phase relationship; Van Enckevort and Wijnberg, 1999; Fig. 5a), and that of shoreward perturbations in the inner bar facing outer-bar horns (a $0^{\circ}$, or in-phase relationship; Bowman and Goldsmith, 1983; Castelle et al., 2007; Fig. 5c). The out-of-phase relationship is reminiscent of the commonly observed relationship between inner-bar patterns and shoreline rhythms (Sonu, 1973; Orzech et al., 2011; Fig. 5b). Additionally, Ruessink et al. (2007a) and Quartel (2009) found coupled sandbar patterns with gradual phase changes (ranging from 0 to $180^{\circ}$ ), thought to be related to the persistent non-zero angle of wave incidence and larger alongshore migration rates of the subtidal bar with respect to the inner bar, respectively.

The aforementioned field observations of sandbar coupling were either based on sporadic observations (e.g. Bowman and Goldsmith, 1983; Castelle et al., 2007) or a short single event (e.g. Ruessink et al., 2007a). Although this previous work has provided clear examples of the phenomenon of sandbar coupling, the frequency or predominance of either of the coupling patterns remained unclear. As a first step towards understanding when and how often certain coupling types develop, we addressed the representativeness of these findings using the barlines derived from the low-tide timeexposure video images. Cross-correlation of the barlines allowed detecting coupled inner- and outer-bar morphology (Price and Ruessink, 2013). Intriguingly, $40 \%$ of all observations were found to have statistically significant (at the $98 \%$ confidence level) coupling. The images unveiled five characteristic coupling types (Fig. 6). The bars either coupled inphase, with an outer-bar horn facing a shoreward perturbation of the inner barline, or out-of-phase, where the outerbar horn coincided with a seaward bulge in the inner barline. Four of the five observed coupling types coincided with a downstate sequence of the outer bar. The morphology of the inner bar was found to be either terraced (with no trough or channels intersecting the bar) or characterised by the presence of rip channels. These properties were used to give abbreviated names to the coupling types (Fig. 6): I or O (inphase or out-of-phase), $\mathrm{d}$ or $\mathrm{u}$ (downstate or upstate) and $\mathrm{t}$ or $\mathrm{r}$ (terraced or with rips). By far the most common coupling type at the Gold Coast was, however, the Idt type, with a wavy terraced inner bar showing landward perturbations displaced slightly $(\approx 100 \mathrm{~m})$ alongshore with respect to the outer-bar horns (Fig. 6a and Fig. 2). This coupling type corresponds to the coupled morphology observed by Ruessink et al. (2007a) at the same site.

Using a numerical model with synthetic wave-input conditions and bathymetries, Castelle et al. (2010a) demonstrated that, under shore-normal waves, coupling processes arise because of alongshore variability in wave height, and associated flow patterns over the inner bar that are induced by the water depth variability along the outer-bar crest. As summarised in Fig. 7, a large fraction of wave breaking over the outer bar leads to out-of-phase coupled sandbars (Fig. 7a). For a small fraction of wave breaking, wave focusing by refraction over the outer-bar horns overwhelms the effect of wave breaking, leading to in-phase coupled sandbars (Fig. 7b). Figure 8 summarises the Gold Coast observations in a conceptual model, in which the type of coupling is governed by the offshore wave height, the angle of wave incidence and the depth variation along the outer bar. The two coupling types explored in Castelle et al. (2010a), under shore-normal wave incidence, correspond to Odr (Fig. 7a) and Idr (Fig. 7b). The predominance of the Idt coupling type is related to the fairly large waves that persistently arrive with a large angle of incidence $\left(30^{\circ}\right)$. We hypothesised that such wave conditions drive a meandering alongshore current (Sonu, 1972; MacMahan et al., 2010) that prevents the outer-bar horns from welding to the inner bar and leads to downdrift-positioned landward perturbations in the inner terrace. When the meandering current is less strong (smaller wave height or more shore-normal incidence), the outer-bar horns can weld ashore and lead to the Odt coupling type. 

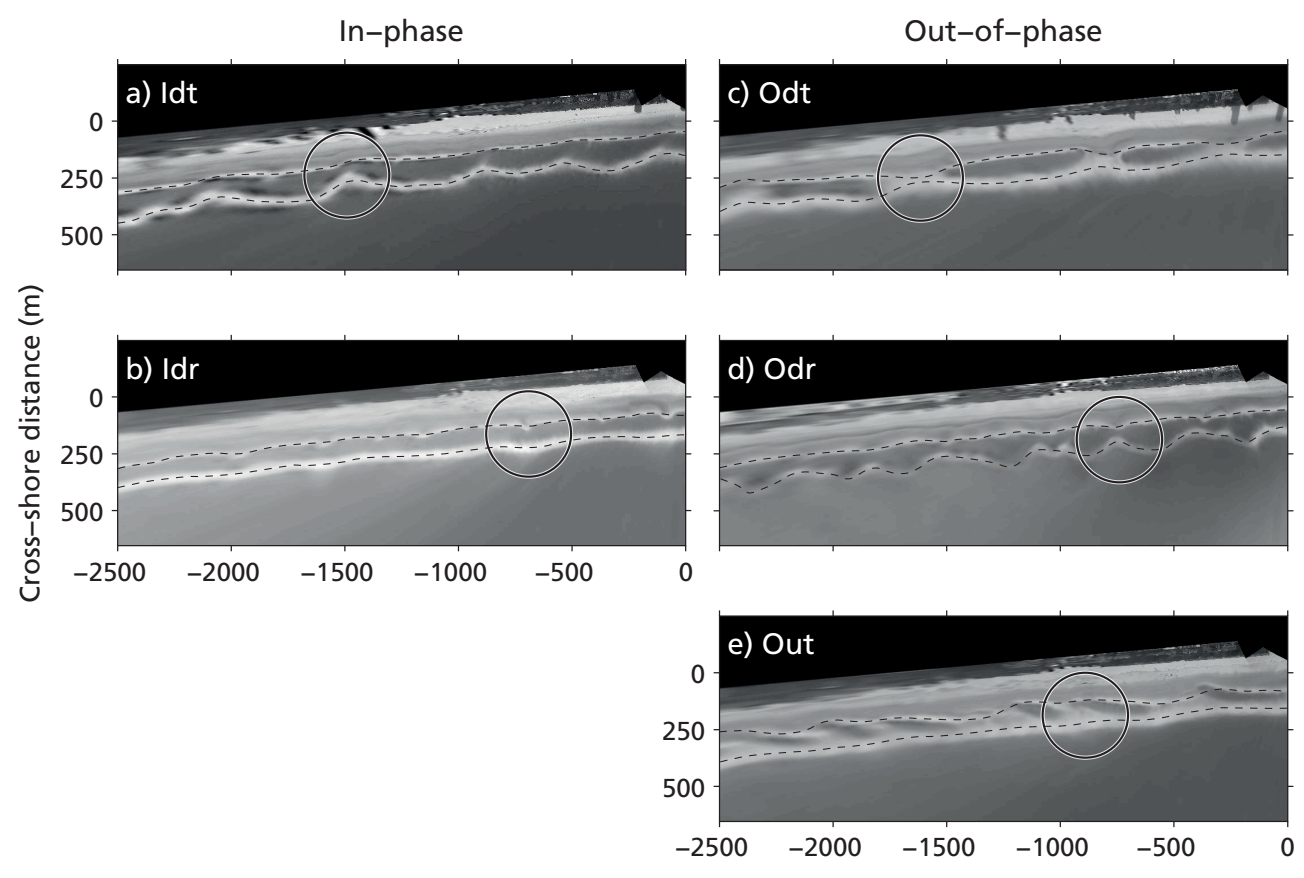

Alongshore distance $(\mathrm{m})$

Figure 6. Examples of observed types of morphological coupling between the inner and outer barlines; low-tide time-exposure plan-view images of in-phase images with (a) an inner terrace and (b) inner rips, out-of-phase coupling with (c) an inner terrace and (d) inner rips in downstate direction, and (e) out-of-phase coupling with a clear alongshore offset between the inner- and outer-barline features in upstate direction. The dotted lines indicate the detected barlines, and the circles indicate a characteristic coupling feature for each coupling type. Source: Price and Ruessink (2013).
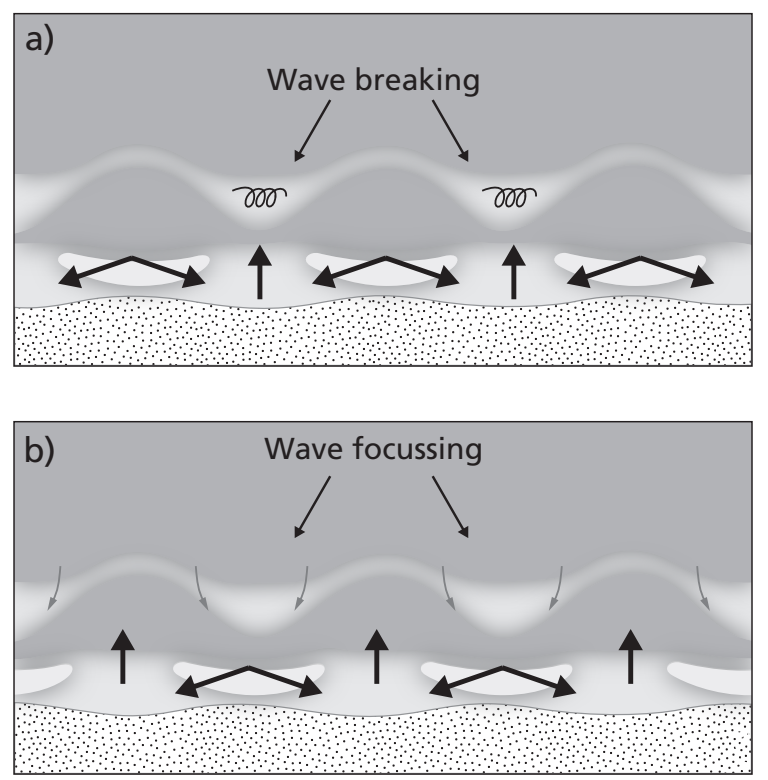

Figure 7. Coupling patterns found by Castelle et al. (2010a), showing (a) out-of-phase coupling and (b) in-phase coupling, depending on the wave height $H$. The thick black arrows indicate the associate flow patterns, whereas the gray arrows indicate wave refraction.
When the waves are highly energetic and obliquely incident, the outer bar becomes more alongshore-uniform (see also Sect. 2); the outer-bar horns separate from the outer bar to become part of the inner bar (similar to Almar et al., 2010), resulting in an alongshore variable inner terrace, the upstate coupling type Out. If the straightening persists, both bars become alongshore-uniform with alongshore continuous troughs. A sudden change toward the end of this straightening, however, leads to the Idr coupling type. Now, the small remaining depth variations along the outer bar cause wave focussing through refraction, driving a weak cell-circulation pattern over the inner bar (see also Fig. 7b).

Although the alongshore variability in the inner bar is coupled to that in the outer bar for some $40 \%$ of the time at the Gold Coast, it remains unknown to what extent these observations represent the behaviour of other double-barred beaches. Similar to the observed behaviour at the Gold Coast (also see Ruessink et al., 2007a), observations from Duck Beach (North Carolina, USA) show the formation of an Idt coupling type, following a period of obliquely incident, moderately energetic waves (Fig. 9).

In a follow-up study, Castelle et al. (2010b) demonstrated that self-organisation and coupling processes can co-exist on an inner bar. In fact, their modelling suggests that the combination of both processes leads to stronger variability in the alongshore inner-bar scales, rather than 

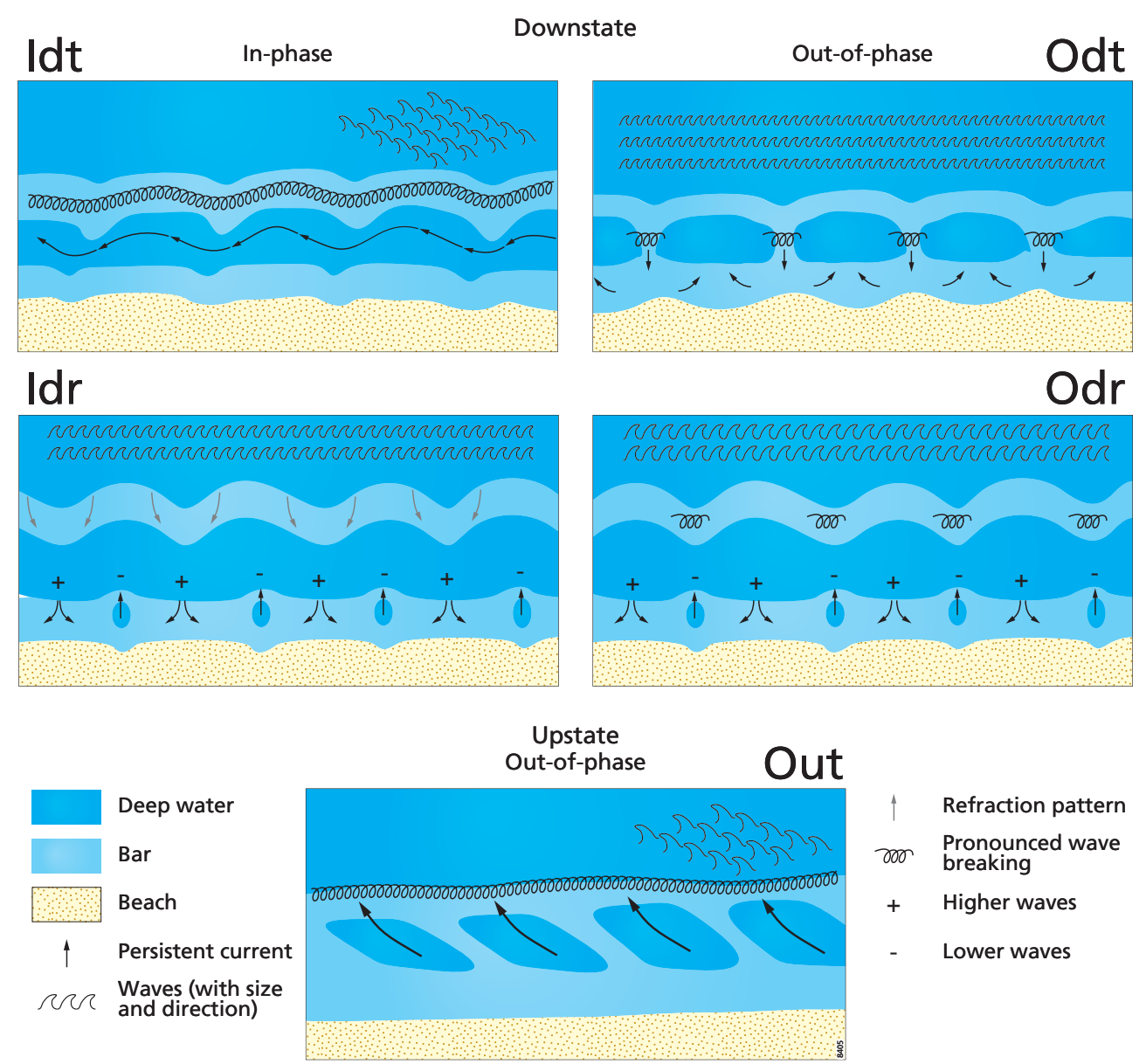

Figure 8. Conceptual model of the development of different coupling types.

self-organisational processes alone, as in single bar systems. They further demonstrated that the relative importance of self-organisation and morphological coupling changes in favour of the latter with an increase in water depth variability along the outer-bar crest. An analysis of an event during which an Idt coupling type formed, however, indicated that, under oblique wave incidence, it was not necessarily the alongshore depth variation but the alongshore shape of the outer bar which is important for altering the wave and current fields at the inner bar (Price and Ruessink, 2013). In the next section, we further discuss the role of the angle of wave incidence for the development of different coupling types.

\subsection{Modelling}

Although video observations provide a high-frequency longterm data set of coupled sandbar morphology, numerical models are often used to shed light on the processes underlying the observed morphodynamics. So far, numerical studies of sandbar morphology have largely focussed on single-barred beaches (e.g. Ranasinghe et al., 2004; Reniers et al., 2004; Garnier et al., 2006; Tiessen et al., 2011). The few existing numerical studies of double sandbar systems have mainly focussed on the initial development and subsequent evolution of crescentic patterns, either using linear stability analysis (e.g. Klein and Schuttelaars, 2006; Garnier et al., 2008; Coco and Calvete, 2009; Brivois et al., 2012), nonlinear depth-averaged models (Klein and Schuttelaars, 2006; Smit et al., 2008, 2012; Thiébot et al., 2012), or quasi-three-dimensional models (Drønen and Deigaard, 2007). Whereas the simulations of Castelle et al. (2010a, b) were performed for shore-normal wave incidence only, Thiébot et al. (2012) performed numerical simulations for a large range of wave angles over initially alongshore-uniform sandbars. For slightly obliquely incident waves (10 and $15^{\circ}$ with respect to shore normal at $8 \mathrm{~m}$ water depth), they found that initially the inner bar did not develop any alongshore variability due to the large alongshore current. However, when the outer bar started to develop alongshore variability, the alongshore current and the incoming wave field at the inner bar became perturbed, leading to the development of inner-bar features with an alongshore spacing similar to that of the outer-bar horns. 

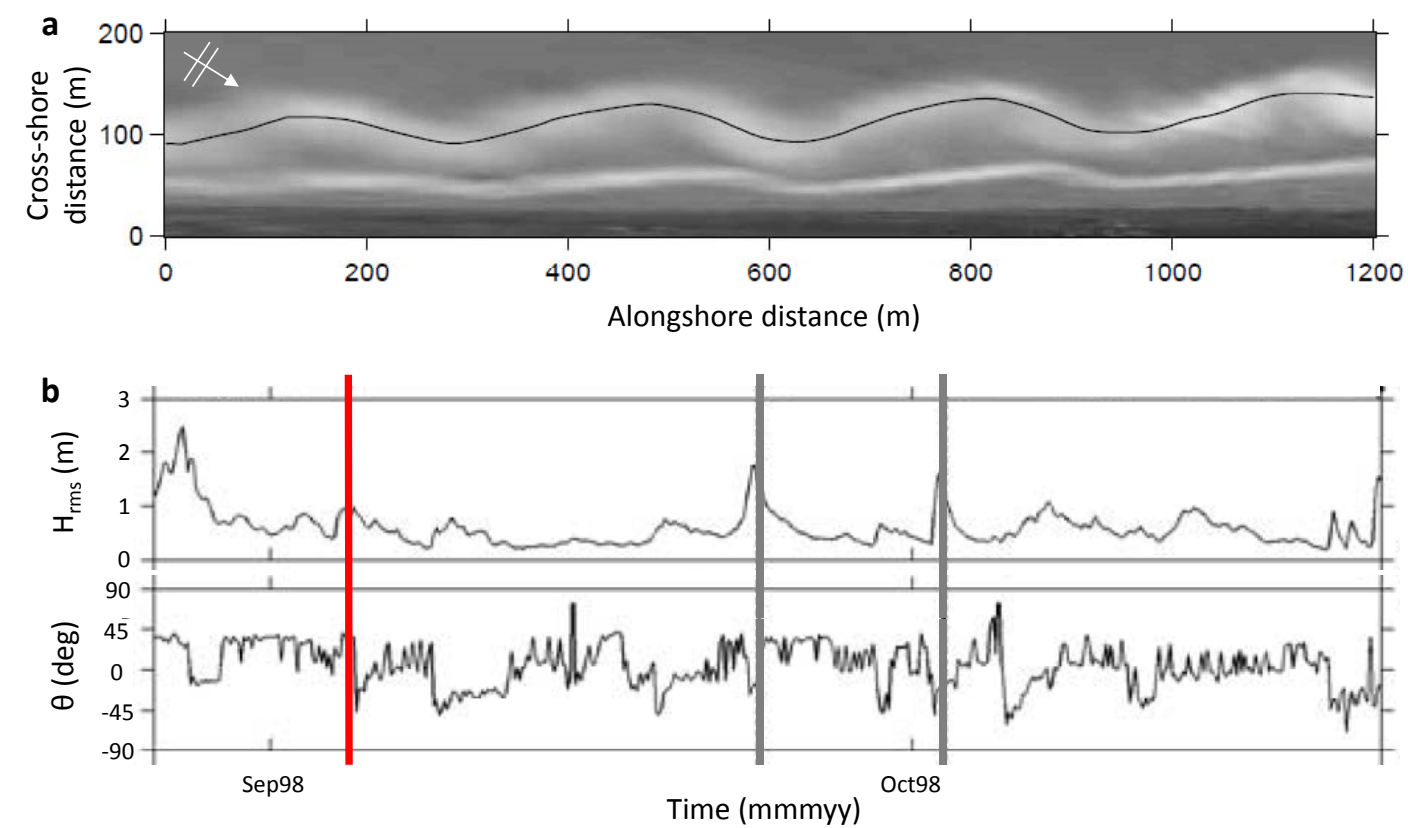

Figure 9. Example of the Idt coupling type observed at Duck, NC, USA. The video image in (a) is from 4 September 1998 , indicated by the solid red line in the time series in (b), showing the offshore root-mean-square wave height $H_{\text {rms }}$ (top) and angle of wave incidence with respect to shore normal $\theta$ (bottom). The solid grey lines correspond to moments when an existing crescentic pattern was wiped out, see Van Enckevort et al. (2004). Adapted from Van Enckevort and Ruessink (2003) (a) and Van Enckevort et al. (2004) (b).

Building upon the hypotheses from Castelle et al. (2010a) for shore-normal wave incidence and the video observations from the Gold Coast, Price et al. (2013) applied the nonlinear 2DH (two horizontal dimensions) numerical model of Castelle et al. (2010a) to explore why different angles of wave incidence lead to the development of different coupling types. Modelling the finite-amplitude behaviour of nearshore bars, however, requires correct estimates of the initial bathymetric state. As bathymetric surveys of crescentic sandbar systems are scarce, they used the assimilation model of Van Dongeren et al. (2008) to estimate depth variations from the video images. This contrasts with earlier modelling efforts of double-barred systems, which used synthetic or highly idealised bathymetries. The boundary conditions for the simulations were extracted from a representative 4-day period during which the development of an Idt coupling type was observed in time-exposure video images. Subsequently, the model was run with time-invariant forcing (offshore significant wave height and period of $1.1 \mathrm{~m}$ and $9 \mathrm{~s}$, respectively) for angles of wave incidence $\theta$ ranging from 0 to $20^{\circ}$, with an initially crescentic outer bar ((see Price et al., 2013, for details)).

Figure 10 shows the flow pattern along the inner bar for all $\theta$ (in $15 \mathrm{~m}$ depth) simulations after 2 days of simulation. Here, the grey scaling indicates the strength of the rotational nature of the flow, termed the swirling strength, over the inner bar. It can be seen that the flow is rotational (i.e. contains cell-circulation patterns) for angles of wave incidence of up to $\approx 10^{\circ}$. As $\theta$ approaches $10^{\circ}$, the feeder current directly downdrift of the rip channel becomes weaker and eventually disappears as it becomes overridden by the alongshore current. Now, the flow field above the inner bar is dominated by a meandering alongshore current. Figure 11 shows the depth perturbations along the inner bar after 2 days of simulation. The most pronounced depth perturbations are found for the simulations with $\theta=7^{\circ}$, which are relatively deep and narrow. As the flow is still rotational (see Fig. 10), these negative perturbations correspond to rip channels. For larger angles, the negative depth perturbations decrease and become increasingly wider. Toward $\theta=20^{\circ}$, the depth perturbations have hardly developed at all. When we examine the simulations for $\theta=10-20^{\circ}$ in more detail, we find that the meandering alongshore current erodes the inner terrace downstream of the outer-bar horns, where more onshore-directed flow and accretion turn to more offshore-directed flow and erosion. This results in a landward perturbation in the terrace edge, consistent with the observations of the Idt coupling type. As such, the landward perturbations in the inner terrace for the Idt coupling type are erosional features. For $\theta<10^{\circ}$, cell-circulation patterns govern the flow at the inner bar, with offshore flow and the development of rip channels in the inner bar at the locations of the outer-bar horns, the Odr coupling type also found by Castelle et al. (2010a). On the whole, Figs. 10 and 11 confirm that the angle of wave incidence is crucial to the flow pattern, sediment transport, and thus the emerging coupling type at the inner bar. 

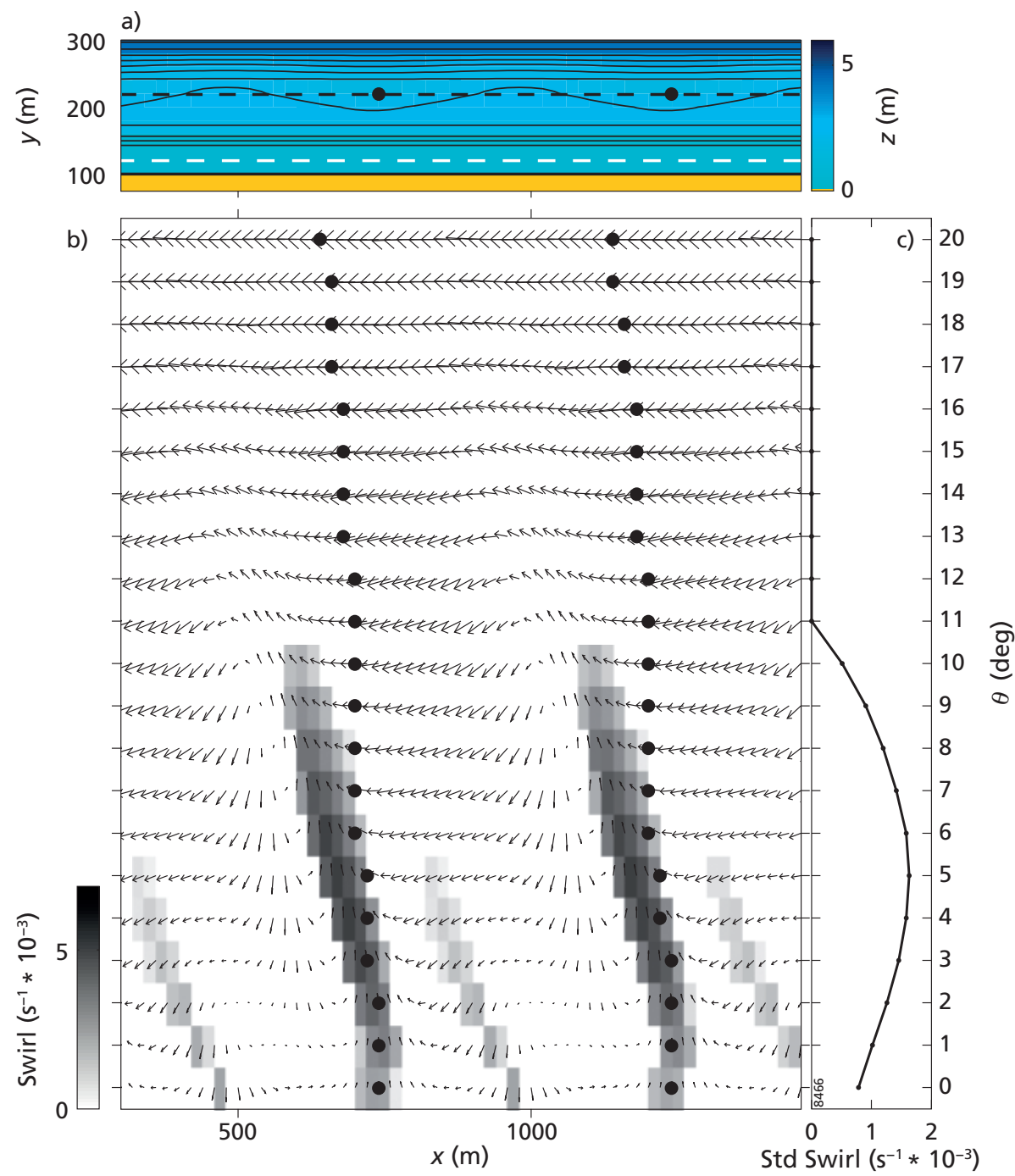

Figure 10. Model results, showing (a) the initial bathymetry, with isobaths ( $0.5 \mathrm{~m}$ intervals) contoured in the background, (b) flow velocity $\boldsymbol{U}$ (arrows) and swirling strength (shaded) along the inner bar at $y=120 \mathrm{~m}$ for all simulations after 2 days of simulation, and (c) the corresponding standard deviation of the swirling strength along the inner bar at $y=120 \mathrm{~m}$. The black dots in (a) and (b) indicate the alongshore positions of the outer-bar horns along $y=220 \mathrm{~m}$. The swirling strength is a measure of the rotational nature of the flow. Non-zero values imply the presence of cell-circulation patterns. Source: Price et al. (2013).

It is somewhat surprising that the most pronounced rip channels are found for the simulations with $\theta$ around $7^{\circ}$ (Fig. 11), as previous modelling exercises of single bar systems (e.g. Castelle and Ruessink, 2011) found that rip channels were more pronounced when formed during shorenormal wave incidence. Also notice that the depth perturbations are located further to the left (downdrift) for larger angles of wave incidence. These findings may both be explained through the combination of the increased magnitude of the alongshore current on the one hand, and the alongshore migration and evolution of the outer bar (the morphological template for the inner bar) on the other hand (indicated by the black dots in Figs. 10 and 11a, b). Figure 11c shows that for small angles of wave incidence (up to $\theta=7^{\circ}$ ), the alongshore variability of the outer bar increases with respect to the initial alongshore variability within the 2-day simulation period, whereas the outer bar becomes more alongshore-uniform for larger angles of wave incidence $\left(\theta>7^{\circ}\right)$, corresponding with our observations (see Sect. 2; Price and Ruessink, 2011). Although the inner-bar depth perturbations follow the alongshore migration of the outer-bar horns at first, the straightening of the outer bar reduces the effect of the outer-bar morphological template on the inner-bar flow pattern, inhibiting the further development of inner-bar features as the flow pattern becomes alongshore-uniform. The numerical model study of Garnier et al. (2013) also stresses the effect of wave obliquity and the associated meandering current pattern in bar straightening. Their results indicated that the rip currents 


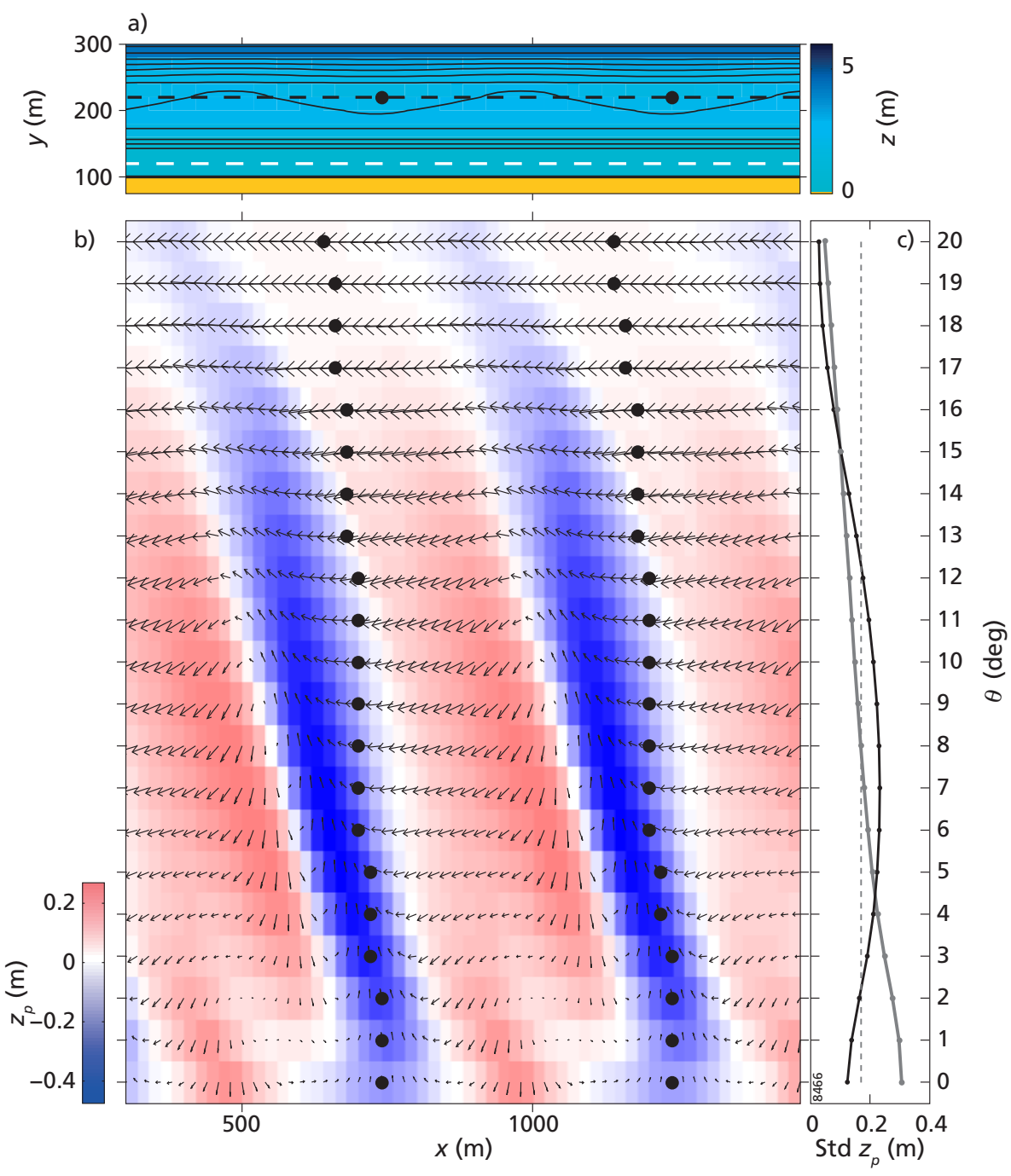

Figure 11. Model results, showing (a) the initial bathymetry, with isobaths ( $0.5 \mathrm{~m}$ intervals) contoured in the background, (b) flow velocity $\boldsymbol{U}$ (arrows) and depth perturbations $z_{\mathrm{p}}$ (colour) along the inner bar at $y=120 \mathrm{~m}$ (white dashed line in (a) for all simulations after 2 days of simulation). (c) depicts the alongshore standard deviation of $z_{\mathrm{p}}$ along the inner bar at $y=120 \mathrm{~m}$ (black) and the outer bar at $y=220 \mathrm{~m}$ (grey), and the initial standard deviation of $z_{\mathrm{p}}$ along the outer bar at $y=220 \mathrm{~m}$ (dashed). The black dots in (a) and (b) indicate the alongshore positions of the outer-bar horns along $y=220 \mathrm{~m}$. Source: Price et al. (2013).

through the bays weakened in intensity with an increase in $\theta$ and that, at the same time, the strongest current shifted to a location downstream of the deepest part of the bay. As in Fig. 11, this shift causes the rip channels to migrate and decay. Interestingly, the transition from rip growth to rip decay at the outer bar takes place at substantially lower $\theta$ (say, $5-10^{\circ}$ ) than in the observations (Fig. $3, \theta \approx 30^{\circ}$ ). Similarly, Thiébot et al. (2012) showed that under slightly oblique wave incidence inner-bar perturbations did not develop before the growth of outer-bar perturbations.

\section{Conclusions and perspectives}

To summarise, the individual sandbars in a double-barred system should not be studied as independent features, but, instead, the interaction within the composite sandbar system should be taken into account. Morphological coupling is an inherent property of double sandbar systems. Accordingly, in double-barred systems, the inner bar may attain a type of morphology not found in single bar systems. Coupling is predominant when the outer bar is alongshore variable, both in position and depth, except for excessively large offshore angles of incidence or wave heights, leading to outerbar straightening and sandbar de-coupling. From various observations of double sandbar systems, characteristic coupling types are distinguished. In addition to offshore wave height 
and depth variation along the outer bar, the offshore angle of wave incidence is crucial to the type of coupling that emerges. It strongly controls the type of flow pattern over the inner bar, with a change from cell-circulation patterns for approximately shore-normal waves to an alongshore meandering current as the angle increases.

Further work is necessary to test the generality of the findings from our Gold Coast study. The obtained results and the developed and applied methodology provide a framework for studying and describing similar data sets of multiple sandbar systems. In general, we expect intersite variability to arise from differences in sandbar mobility, which, in turn, is ascribed to sandbar volume, grain size, bottom slope, tidal range, and wave climate (e.g. see Wright and Short, 1984; Masselink and Short, 1993; Shand et al., 1999). More generally, as also suggested by Pape et al. (2010), intersite differences in sandbar behaviour are expected to depend on the ratio between the response time of a sandbar and the variability of the wave climate. Besides identifying the role of these potential variables through intersite comparison, numerical modelling becomes essential in testing the concepts formed. For example, a numerical model with different initial inner-bar morphologies, and time-variant wave forcing could shed light on this aspect of morphological coupling behaviour (see also Drønen and Deigaard, 2007; Garnier et al., 2008; Castelle and Ruessink, 2011; Tiessen et al., 2011; Smit et al., 2012). Moreover, from this, it would be interesting to assess changes in the ratio between self-organisation processes and outer-bar forced development of the inner bar (see also Castelle et al., 2010b).

In Sect. 3.2, the assimilation model of Van Dongeren et al. (2008) provided the initial bathymetric state for the numerical modelling, based on time-exposure images. Although previous work has been devoted to unravel how the observed foam relates to, for example, the roller dissipation (Aarninkhof and Ruessink, 2004; Alexander and Holman, 2004), further investigation into the relation between the observed foam and the measured wave properties on a natural beach would likely benefit the use of this assimilation technique at other sites with scarce amounts of data (see e.g. Birrien et al., 2013). Moreover, it is expected that the inclusion of multiple proxies for the bathymetry, such as wave celerity (e.g. Wilson et al., 2010), wave height (Almar et al., 2012; Gal et al., 2014), and cross-shore wave height profiles from terrestrial laser scanners (Belmont et al., 2007; Blenkinsopp et al., 2012), will enhance the assimilation results (Van Dongeren et al., 2008), and ultimately improve our understanding of finite-amplitude sandbar behaviour.

Although this review focussed on the alongshore variability of a double sandbar system, the observed effect of the outer bar on the inner-bar morphodynamics implicitly includes a cross-shore aspect. In fact, recent research (Plant et al., 2006; Splinter et al., 2011) has indicated that alongshore variations in bar crest position affect the alongshoreuniform behaviour. It was found that the horizontal cell- circulation coinciding with the growth of alongshore variability facilitates onshore migration under low-energetic conditions. Analogously, a decrease in three-dimensionality in the outer bar coincides with offshore migration of the outer bar. Although this offshore migration has been suggested to be driven by the increased undertow over the bar during high-energetic events, it remains unknown whether undertow leads to the straightening of the bar. Both observations (Sect. 2) and modelling results (Sect. 3.2) show that sandbars do not necessarily straighten during storms, with large wave heights, but that obliquely incident waves play a crucial role in the straightening of the bar through the generation of an alongshore current. Process-based models that focus on cross-shore migration (e.g. Hoefel and Elgar, 2003; Ruessink et al., 2007b, 2012) or on alongshore variability (e.g. Reniers et al., 2004; Calvete et al., 2005; Drønen and Deigaard, 2007; Castelle and Coco, 2012) alone, have become quite mature. The key challenge will be to integrate both model concepts into a single model that can adequately simulate the complete dynamics of double sandbar systems. As such, understanding the alongshore variable sandbar behaviour will also lead to improved understanding of cross-shore behaviour.

Acknowledgements. We wish to thank Giovanni Coco and two anonymous referees for their constructive comments, which significantly improved this review. We acknowledge financial support by the Netherlands Organisation for Scientific Research (NWO) under contract 818.01.009 and by the French BARBEC project under contract ANR N2010JCJC60201. We thank Ian Turner for the use of the Gold Coast video imagery.

Edited by: G. Coco

\section{References}

Aarninkhof, S. G. J. and Ruessink, B. G.: Video observations and model predictions of depth-induced wave dissipation, IEEE Trans. Geosci. Remote Sens., 42, 2612-2622, 2004.

Alexander, P. S. and Holman, R. A.: Quantification of nearshore morphology based on video imaging, Mar. Geol., 208, 101-111, 2004.

Almar, R., Castelle, B., Ruessink, B. G., Sénéchal, N., Bonneton, P., and Marieu, V.: Two- and three-dimensional double sandbar system behaviour under intense wave forcing and a meso-macro tidal range, Cont. Shelf Res., 30, 781-792, 2010.

Almar, R., Cienfuegos, R., Catalán, P. A., Michallet, H., Castelle, B., Bonneton, P., and Marieu, V.: A new breaking wave height direct estimator from video imagery, Coast. Engin., 61, 42-48, 2012.

Belmont, M. R., Horwood, J. M. K., Thurley, R. W. F., and Baker, J.: Shallow Angle Wave Profiling Lidar, J. Atmos. Ocean. Technol., 24, 1150-1156, 2007.

Birrien, F., Castelle, B., Marieu, V., and Dubarbier, B.: On a datamodel assimilation method to inverse wave-dominated beach bathymetry using heterogeneous video-derived observations, Ocean Engin., 73, 126-138, 2013. 
Blenkinsopp, C. E., Turner, I. L., Allis, M. J., Peirson, W. L., and Garden, L. E.: Application of LiDAR technology for measurement of time-varying free-surface profiles in a laboratory wave flume, Coast. Engin., 68, 1-5, 2012.

Bowman, D. and Goldsmith, V.: Bar morphology of dissipative beaches: An empirical model, Mar. Geol., 51, 15-33, 1983.

Bowen, A. J. and Inman, D. L.: Edge Waves and Crescentic Bars, J. Geophys. Res., 76, 8662-8671, 1971.

Brander, R. W.: Field observations on the morphodynamic evolution of a low-energy rip current system, Mar. Geol., 157, 199-217, 1999.

Brivois, O., Idier, D., Thiébot, J., Castelle, B., Cozannet, G. L., and Calvete, D.: On the use of linear stability model to characterize the morphological behaviour of a double bar system. Application to Truc Vert beach (France), Comptes Rendus Geosci., 344, 277287, 2012.

Calvete, D., Dodd, N., Falqués, A., and van Leeuwen, S. M.: Morphological development of rip channel systems: Normal and near-normal wave incidence, J. Geophys. Res., 110, C10006, doi:10.1029/2004JC002803, 2005.

Castelle, B. and Coco, G.: The morphodynamics of rip channels on embayed beaches, Conti. Shelf Res., 43, 10-23, 2012.

Castelle, B. and Ruessink, B. G.: Modeling formation and subsequent nonlinear evolution of rip channels: time-varying versus time-invariant wave forcing, J. Geophys. Res., 116, F04008, doi:10.1029/2011JF001997, 2011.

Castelle, B., Bonneton, P., Dupuis, H., and Sénéchal, N.: Double bar beach dynamics on the high-energy meso-macrotidal French Aquitanian Coast: A review, Mar. Geol., 245, 141-159, 2007.

Castelle, B., Ruessink, B. G., Bonneton, P., Marieu, V., Bruneau, N., and Price, T. D.: Coupling mechanisms in double sandbar systems, Part 1: Patterns and physical explanation, Earth Surf. Proc. Landforms, 35, 476-486, 2010a.

Castelle, B., Ruessink, B. G., Bonneton, P., Marieu, V., Bruneau, N., and Price, T. D.: Coupling mechanisms in double sandbar systems, Part 2: Impact on alongshore variability of inner-bar rip channels, Earth Surf. Proc. Landforms, 35, 771-781, 2010b.

Coco, G. and Calvete, D.: The use of linear stability analysis to characterize the variability of multiple sandbar systems, in: Proceedings of Coastal Dynamics 2009, Tokyo, Japan, paper no. 53, doi:10.1142/9789814282475_0055, 2009.

Coco, G. and Murray, A. B.: Patterns in the sand: From forcing templates to self-organization, Geomorphology, 91, 271-290, 2007.

Drønen, N. and Deigaard, R.: Quasi-three-dimensional modelling of the morphology of longshore bars, Coast. Engin., 54, 197215, 2007.

Evans, O. F.: The low and ball of the eastern shore of lake michigan, The J. Geol., 48, 476-511, 1940.

Falqués, A., Coco, G., and Huntley, D.: A mechanism for the generation of wave-driven rhythmic patterns in the surf zone, J. Geophys. Res., 105, 24071-24087, doi:10.1029/2000JC900100, 2000.

Ferrer, P., Certain, R., Barusseau, J. P., and Gervais, M.: Conceptual modelling of a double crescentic barred coast (Leucate beach, France), in: Proceedings Coastal Dynamics 2009, Tokyo, Japan, 2009.

Gal, Y., Browne, M., and Lane, C.: Long-term automated monitoring of nearshore wave height from digital video, IEEE Trans. Geosci. Remote Sens., 52, 3412-3420, 2014.
Garnier, R., Calvete, D., Falques, A., and Caballeria, M.: Generation and nonlinear evolution of shore-oblique-transverse sand bars, J. Fluid Mechan., 567, 327-360, 2006.

Garnier, R., Calvete, D., Dodd, N., and Falqués, A.: Modelling the interaction between transverse and crescentic bar systems, in: River, Coastal and Estuarine Morphodynamics: RCEM 2007, edited by: Dohmen-Jansen, C. M. and Hulscher, S. J. M. H., vol. 2, Taylor and Francis Group, London, 931-937, 2008.

Garnier, R., Falqués, A., Calvete, D., Thiébot, J., and Ribas, F.: A mechanism for sand bar straightening by oblique wave incidence, Geophys. Res. Lett., 40, 2726-2730, 2013.

Goldsmith, V., Bowman, D., and Kiley, K.: Sequential stage development of crescentic bars: HaHoterim beach, southeastern Mediterranean, J. Sediment. Petrol., 52, 233-249, 1982.

Greenwood, B. and Davidson-Arnott, R. G. D.: Marine bars and nearshore sedimentary processes, Kouchibouguac Bay, New Brunswick, Canada, Nearshore sediment dynamics and sedimentation, 16, 123-150, 1975.

Grunnet, N. M. and Ruessink, B.: Morphodynamic response of nearshore bars to a shoreface nourishment, Coast. Engin., 52, 119-137, 2005.

Hino, M.: Theory on formation of rip-current and cuspidal coast, in: Proc. 14th Conf. Coastal Eng., Copenhagen, Denmark, Am. Soc. Civ. Eng., 901-919, 1975.

Hoefel, F. and Elgar, S.: Wave-Induced Sediment Transport and Sandbar Migration, Science, 299, 1885-1887, 2003.

Holman, R. A. and Bowen, A. J.: Bars, bumps, and holes: Models for the generation of complex beach topography, J. Geophys. Res., 87, 457-468, 1982.

Holman, R. A. and Stanley, J.: The history and technical capabilities of Argus, Coast. Engin., 54, 477-491, 2007.

Houser, C., Arnott, R., Ulzhöfer, S., and Barrett, G.: Nearshore circulation over transverse bar and rip morphology with oblique wave forcing, Earth Surf. Proc. Landforms, 38, 1269-1279, 2013.

Klein, M. D. and Schuttelaars, H. M.: Morphodynamic evolution of double-barred beaches, J. Geophys. Res., 111, C06017, doi:10.1029/2005JC003155, 2006.

Kuriyama, Y.: Medium-term bar behavior and associated sediment transport at Hasaki, Japan, J. Geophys. Res., 107, 3132, doi:10.1029/2001JC000899, 2002.

Lippmann, T. and Holman, R.: Quantification of sand bar morphology: a video technique based on wave dissipation, J. Geophys. Res., 94, 995-1011, 1989.

Lippmann, T. C. and Holman, R. A.: The spatial and temporal variability of sand bar morphology, J. Geophys. Res., 95, 1157511590, 1990.

Lippmann, T. C., Holman, R. A., and Hathaway, K. K.: Episodic, nonstationary behavior of a double bar system at Duck, North Carolina, U.S.A., 1986-1991, J. Coast. Res., SI15, 49-75, 1993.

MacMahan, J., Brown, J., Brown, J., Thornton, E., Reniers, A., Stanton, T., Henriquez, M., Gallagher, E., Morrison, J., Austin, M. J., Scott, T. M., and Senechal, N.: Mean Lagrangian flow behavior on an open coast rip-channeled beach: A new perspective, Mar. Geol., 268, 1-15, 2010.

Masselink, G. and Short, A. D.: The effect of tide range on beach morphodynamics and morphology: A conceptual beach model, J. Coast. Res., 9, 785-800, 1993. 
Ojeda, E. and Guillén, J.: Shoreline dynamics and beach rotation of artificial embayed beaches, Mar. Geol., 253, 51-62, 2008.

Orzech, M. D., Reniers, A. J. H. M., Thornton, E. B., and MacMahan, J. H.: Megacusps on rip channel bathymetry: Observations and modeling, Coast. Engin., 58, 890-907, 2011.

Pape, L., Plant, N. G., and Ruessink, B. G.: On cross-shore migration and equilibrium states of nearshore sandbars, J. Geophys. Res., 115, F03008, doi:10.1029/2009JF001501, 2010.

Plant, N. G., Holland, K. T., and Holman, R. A.: A dynamical attractor governs beach response to storms, Geophys. Res. Lett., 33, L17607, doi:10.1029/2006GL027105, 2006.

Price, T. D. and Ruessink, B. G.: State dynamics of a double sandbar system, Continen. Shelf Res., 31, 659-674, 2011.

Price, T. D. and Ruessink, B. G.: Observations and conceptual modelling of morphological coupling in a double sandbar system, Earth Surf. Proc. Landforms, 38, 477-489, 2013.

Price, T. D., Castelle, B., Ranasinghe, R., and Ruessink, B. G.: Coupled sandbar patterns and obliquely incident waves, J. Geophys. Res., 118, 1677-1692, 2013.

Quartel, S.: Temporal and spatial behaviour of rip channels in a multiple-barred coastal system, Earth Surf. Proc. Landforms, 34, 163-176, 2009.

Ranasinghe, R., Symonds, G., Black, K., and Holman, R.: Morphodynamics of intermediate beaches: a video imaging and numerical modelling study, Coast. Engin., 51, 629-655, 2004.

Reniers, A. J. H. M., Roelvink, J. A., and Thornton, E. B.: Morphodynamic modeling of an embayed beach under wave group forcing, J. Geophys. Res., 109, C01030, doi:10.1029/2002JC001586, 2004.

Ruessink, B., Ramaekers, G., and van Rijn, L.: On the parameterization of the free-stream non-linear wave orbital motion in nearshore morphodynamic models, Coast. Engin., 65, 56-63, doi:10.1016/j.coastaleng.2012.03.006, 2012.

Ruessink, B. G. and Kroon, A.: The behaviour of a multiple bar system in the nearshore zone of Terschelling, the Netherlands: 1965-1993, Mar. Geol., 121, 187-197, 1994.

Ruessink, B. G., Wijnberg, K. M., Holman, R. A., Kuriyama, Y., and van Enckevort, I. M. J.: Intersite comparison of interannual nearshore bar behavior, J. Geophys. Res., 108, 3249, doi:10.1029/2002JC001505, 2003.

Ruessink, B. G., Coco, G., Ranasinghe, R., and Turner, I. L.: Coupled and noncoupled behavior of three-dimensional morphological patterns in a double sandbar system, J. Geophys. Res., 112, C07002, doi:10.1029/2006JC003799, 2007a.

Ruessink, B. G., Kuriyama, Y., Reniers, A. J. H. M., Roelvink, J. A., and Walstra, D. J. R.: Modeling cross-shore sandbar behavior on the timescale of weeks, J. Geophys. Res., 112, F03010, doi:10.1029/2006JF000730, 2007b.

Saylor, J. and Hands, E.: Properties of longshore bars in the Great Lakes, in: Proceedings of the 12th International Conference on Coastal Engineering, 839-853, ASCE, Washington DC, 1970.

Sénéchal, N., Gouriou, T., Castelle, B., Parisot, J. P., Capo, S., Bujan, S., and Howa, H.: Morphodynamic response of a meso- to macro-tidal intermediate beach based on a long-term data set, Geomorphology, 107, 263-274, 2009.

Shand, R. D., Bailey, D. G., and Shepherd, M. J.: An inter-site comparison of net offshore bar migration characteristics and environmental conditinos, J. Coast. Res., 15, 750-765, 1999.
Shand, R. D., Bailey, D. G., Hesp, P. A., and Shepherd, M. J.: Conceptual beach-state model for the inner bar of a storm-dominated, micro/meso tidal range coast at Wanganui, New Zealand, in: Proceedings of Coastal Sediments 2003, Miami, USA, 2003.

Short, A. D. and Aagaard, T.: Single and multi-bar beach change models, Journal of Coastal Research, SI15, 141-157, 1993.

Smit, M., Reniers, A., and Stive, M.: Role of morphological variability in the evolution of nearshore sandbars, Coast. Engin., 69, 19-28, 2012.

Smit, M. W. J., Reniers, A. J. H. M., Ruessink, B. G., and Roelvink, J. A.: The morphological response of a nearshore double sandbar system to constant wave forcing, Coast. Engin., 55, 761-770, 2008.

Sonu, C. J.: Field observation of nearshore circulation and meandering currents, J. Geophys. Res., 77, 3232-3247, 1972.

Sonu, C. J.: Three-dimensional beach changes, J. Geol., 81, 42-64, 1973.

Splinter, K. D., Holman, R. A., and Plant, N. G.: A behavior-oriented dynamic model for sandbar migration and 2DH evolution, J. Geophys. Res., 116, C01020, doi:10.1029/2010JC006382, 2011.

Thiébot, J., Idier, D., Garnier, R., Falqués, A., and Ruessink, B. G.: The influence of wave direction on the morphological response of a double sandbar system, Contin. Shelf Res., 32, 71-85, 2012.

Thornton, E., MacMahan, J., and Sallenger, Jr., A.: Rip currents, mega-cusps, and eroding dunes, Mar. Geol., 240, 151-167, 2007.

Tiessen, M. C. H., Dodd, N., and Garnier, R.: Development of crescentic bars for a periodically perturbed initial bathymetry, J. Geophys. Res., 116, F04016, doi:10.1029/2011JF002069, 2011.

Van de Lageweg, W. I., Bryan, K. R., Coco, G., and Ruessink, B. G.: Observations of shoreline sandbar coupling on an embayed beach, Mar. Geol., 344, 101-114, 2013.

Van Dongeren, A., Plant, N., Cohen, A., Roelvink, J. A., Haller, M. C., and Catalán, P.: Beach Wizard: Nearshore bathymetry estimation through assimilation of model computations and remote observations, Coast. Engin., 55, 1016-1027, 2008.

Van Enckevort, I. M. J. and Ruessink, B. G.: Video observations of nearshore bar behaviour. Part 2: alongshore non-uniform variability, Contin. Shelf Res., 23, 513-532, 2003.

Van Enckevort, I. M. J. and Wijnberg, K. M.: Intra-annual changes in bar plan shape in a triple bar system, in: Proceedings Coastal Sediments 1999, ASCE, New York, 1094-1108, 1999.

Van Enckevort, I. M. J., Ruessink, B. G., Coco, G., Suzuki, K., Turner, I. L., Plant, N. G., and Holman, R. A.: Observations of nearshore crescentic sandbars, J. Geophys. Res., 109, C06028, doi:10.1029/2003JC002214, 2004.

Wijnberg, K. M. and Terwindt, J. H. J.: Extracting decadal morphological behaviour from high-resolution, long-term bathymetric surveys along the Holland coast using eigenfunction analysis, Mar. Geol., 126, 301-330, 1995.

Wilson, G., Özkan Haller, H., and Holman, R.: Data assimilation and bathymetric inversion in a two-dimensional horizontal surf zone model, J. Geophys. Res., 115, C12057, doi:10.1029/2010JC006286, 2010.

Wright, L. D. and Short, A. D.: Morphodynamic variability of surf zones and beaches: a synthesis, Mar. Geol., 56, 93-118, 1984. 